\title{
EPICTETUS AS SOCRATIC MENTOR ${ }^{1}$
}

In Tom Wolfe's most recent novel, A Man In Full, a young Californian, down on his luck, converts a macho sixty-year old tycoon, facing financial ruin, to Stoicism. ${ }^{2}$ The young man, Conrad, has miraculously escaped from the Santa Rita gaol as a result of an earthquake. Shortly before, he had discovered Epictetus in a book called The Stoics, a book he had been sent mistakenly in place of a riveting thriller by his favourite author with the title, The Stoics' Game. He rapidly comes across this passage: 'I [Zeus] gave you a portion of our divinity, a spark from our own fire, the power to act and not to act, the will to get and the will to avoid. If you pay heed to this, you will not groan, you will blame no man, you will flatter none' (p. 398). Conrad is hooked. An innocent among a bunch of hideous felons, he asks himself: 'What would Epictetus have done with this bunch? What could he have done? How could you apply his lessons two thousand years later, in this grimy gray pod, this pigsty full of beasts who grunted about mother-fuckin this and mother-fuckin that?' (p. 410). Conrad memorises chunks of Epictetus. He refers a series of challenges to Zeus, overcomes a thug twice his size, and radiates Stoic strength. At the end, hired as a male nurse in Atlanta for the massive but now ailing Croker, the about-to-be ruined tycoon, Conrad tells Croker about the Stoic Zeus and Epictetus. Croker was on the point of clinching a deal that would have saved him from bankruptcy at the cost of compromising his Georgian sense of honour. Instead, he gives a press conference, disavows all interest in wealth, parrots Epictetus to the bemused Atlanta elite, and walks away from everything that had previously defined his life. At the end we learn that he has become a highly successful televangelist, with a programme called 'The Stoic's Hour'.

Wolfe is a brilliant caricaturist, but in rekindling his earlier novel, the Bonfire of the Vanities, his new focus on Epictetus is more than ironical. Conrad and Croker are the only likeable and three-dimensional figures in the book. Epictetus, we sense, is way

1 This article is the lightly revised version of my 1999 Corbett lecture to the Faculty of Classics, Cambridge University. I am very grateful for this invitation, which gave me the opportunity of catching up with many old friends and meeting a lively group of students.

My work on Epictetus has been greatly stimulated by a graduate seminar I taught at Berkeley in the spring semester of 1999. I am especially grateful to James Ker and to this journal's referee for their comments on the text of the lecture. Socrates' imprint on Epictetus will also be a major theme in a book I hope to complete shortly for Oxford University Press.

2 Wolfe's book is published by Farrar Straus Giroux (New York, 1998). The translations of Epictetus that he includes are drawn from The Stoic and Epicurean Philosophers, ed. Whitney J. Oates (New York, 1940). 
out, but magnificently so - a voice empowering integrity and self-respect against thuggery or unbridled passion for power, luxury and lost youth. The New York Times (2 January, 1999), noting that Wolfe's novel had promoted Epictetus almost to bestseller status, published a piece headed: 'The Stoics have a stand on everything, even on dinner parties and sex'. With a selection of passages, including the timely (in the light of President Clinton's impeachment) 'Refuse, if you can, to take an oath at all, but if that is impossible, refuse as far as circumstances allow' - with such passages, readers were invited to see how their 'New Year's resolutions stack up to Epictetus' principles for living'. ${ }^{3}$

Tom Wolfe's promotion of Epictetus has a millennial ring, but it is more than an eccentricity. Michel Foucault, when smitten with AIDS in the last year of his life, conducted a seminar on Socratic parrhesia; and in various writings, notably Le Souci de soi, he explored the extraordinary devotion to self-cultivation attested for a number of prominent Romans in the first two centuries A.D. ${ }^{4}$ Foucault was influenced by discussions with Pierre Hadot whose books on ancient [especially Hellenistic and Roman] philosophy as 'a way of life' are enjoying a considerable vogue. 5 Jim Stockdale, Ross Perot's running-mate in the 1992 USA presidential election, has written and lectured on how remembered maxims from Epictetus were his only hold on self-respect when he endured two years of solitary confinement in a Vietnam War prison cell. This real-life story influenced Tom Wolfe. ${ }^{6}$

This recent turn to Stoicism in general and to Epictetus in particular merits exploration by those who know far more than I do about popular culture. However, every classicist who reads Wolfe's novel will find it an intriguing mirror to hold up

3 The Chicago Tribune of 22 January, 1999 ran a piece headed 'Epictetus the Stoic is hot again, thanks to Tom Wolfe', and the article noted how sales of Epictetus have shot up. In an interview, published in the San Francisco Examiner Magazine, 29 November 1998, Wolfe tells of how he 'came across an account of an ordeal by an American pilot shot down in Vietnam [James Stockdale]. I remember him saying that if he had not taken a philosophy course at the Naval Academy he would never have survived the ordeal - and the one name that came back to him was Epictetus.' Either Wolfe's source or his memory is in error because Stockdale learned his Epictetus at Stanford University. See J. B. Stockdale, Courage under Fire. Testing Epictetus's Doctrines in a Laboratory of Human Behavior (Stanford, 1993). An extract from this is included in the new Everyman edition of Epictetus, ed. C. Gill (London/Vermont, 1995) 347-9.

${ }^{4}$ Published in English transl. by R. Hurley as The Care of the Self = vol. 3 of M. Foucault's The History of Sexuality (New York, 1986). For the influence of Stoicism on modern ethics, see L. C. Becker, A New' Stoicism (Princeton, 1998), which argues for a 'secular' version of ancient Stoicism, defending this as the basis for an ethical theory that successfully combines virtue with happiness.

5 See P. Hadot, Exercises spirituels et philosophie antique (Paris, 1987), transl. as Philosophy as a Way of Life, by A. Davidson (Oxford and Cambridge, Mass., 1995); La Citadelle intérieure. Introduction alux Pensées de Marc Aurèle (Paris, 1992), transl. as The Inner Citadel. The Meditutions of Marcus Aurelius, by M. Chase (Cambridge, Mass., 1998); and Qu'est-ce que la philosophie antique (Paris, 1995).

6 See above n. 3. Wolfe is not the first American novelist to refer to Epictetus. Theodore Dreiser wrote a novel called The Stoic (1947), the third part of his largely forgotten trilogy about the rise and fall of Frank Cowperwood, also (like Wolfe's Croker) a ruthless tycoon; and in Dreiser's much earlier and celebrated novel, Sister Carrie, we read (p. 434 of the Modern Library ed., New York, 1999): 'It is the unintellectual miser who sweats blood at the loss of a hundred dollars. It is the Epictetus who smiles when the last vestige of physical welfare is removed'. See also the allusion to Epictetus in Jack Higgins' novel Thunder Point (New York, 1994) 143. 
against the historical Epictetus and his educational mission. You have only to read Petronius, Tacitus or Juvenal to enter a world that resembles Wolfe's Atlanta in its satire of excess, self-deception, and shallow posturing. Yet, by the time Epictetus was teaching at Nicopolis from about A.D. 100-130, there are clear signs that a fair number of elite Romans were responding favourably to his and similarly austere instruction. At no other period is it conceivable that a Stoic would soon sit on the Imperial throne, a bearded Marcus Aurelius, following the fashion set by Hadrian at his accession. At that time too we start to find busts of citizens in the guise of philosophers, not only bearded but some even with shoulder-length hair, following the fashion previously set by the likes of the Stoic Euphrates and by Dio Chrysostom. ${ }^{7}$ The parents who sent their sons to attend Epictetus' school must have had a fair idea of the curriculum in advance. They must have known that Epictetus was no Favorinus or Herodes Atticus, the head of a finishing school in eloquence and elegance. Not that Herodes had anything but admiration for Epictetus; we have the record of his caustic put-down of a young and brash would-be Stoic, whom he shamed to silence by having Arrian's record of Epictetus read back to him. ${ }^{8}$

In the broad context, Epictetus was a representative rather than the leader of a trend. He had studied under Musonius Rufus at Rome. Musonius' pupils included other Stoics who became illustrious figures, such as Euphrates, whose claims to admiration by his contemporaries have been recently explored with great insight by Michael Frede. ${ }^{9}$ When Epictetus' words are merely summarised or reduced to their doctrinal content, as in the excerpts Arrian made for the famous Manual, they appear repetitious, sententious, and unremittingly prescriptive. Their effect, when taken in full context, is very different. Then we find ourselves listening to perhaps the most argumentatively and rhetorically complex, urgent and idiosyncratic voice from Roman antiquity. This is the more remarkable because Arrian is the mediator of Epictetus. Precisely how he recorded, edited, or composed his full account of Epictetus' teaching we shall never know. ${ }^{10}$ What we can say for sure is that Arrian has succeeded in conveying a quite unique style of oral instruction.

My questions for this paper are the following. How did Epictetus teach? What does his teaching method tell us about his conception of philosophy and its practical applications? How should we contextualise Epictetus in terms of traditional Roman ideology and education? The answers I shall offer will give a surprisingly extensive and scarcely appreciated prominence to Socrates.

7 See P. Zanker, The Mask of Socrates (Berkeley/Los Angeles, 1995) 256-66.

8 Aulus Gellius I.2.1-13.

9 'Euphrates of Tyre', in R. Sorabji, ed., Aristotle and After, Bulletin of the Institute of Classical Studies, suppl. 68 (London, 1997) 1-12.

11) On Arrian's role in publishing Epictetus, I am completely in agreement with I. Hadot, Simplicius. Commentaire sur le Manuel d'Epictète (Leiden, 1996) 153-4, who defends the essential authenticity of the record; cf. my remarks in 'Epictetus, Marcus Aurelius', in T. J. Luce, ed., Ancient Writers II (New York, 1985) 989-90. This is compatible with R. Dobbin's interesting proposal that Epictetus himself 'took charge of effecting his lectures' transition' to written form, Epictetus. Discourses. Book I (Oxford, 1998) xxi-xxiii. 
I start with some general remarks about Epictetus' dialectical procedure and his audience. The Bodleian MS, which is the principal source of Arrian's collection, opens without a title. At the end of each book, the scribe wrote APPIANOY T $\Omega N$ EПIKTHTOY $\triangle$ IATPIB $\Omega N$, followed by a numeral. Schenkl, the leading modern editor, supplies this at the beginning, and translates diatribōn by dissertationes. ${ }^{\prime \prime}$ Both of these words are used in ancient references to the 'works' of Epictetus, as are the following terms as well: dialexeis, apomnèmoneumata, scholai, and homiliai. ${ }^{12}$ Because all of these words are interchangeable as names for any professional teacher's didactic encounters with his students, we are at liberty to choose the most appropriate description for Arrian's record of Epictetus' work. 'Discourses' is innocuous, but the common practice of calling the texts either 'sermons' or 'diatribes', or interpreting them by means of such expressions, gives the quite misleading impression that Epictetus' discourses in general are instances of pulpit-bashing or haranguing. ${ }^{13}$ There are much better ways of characterising his stylistic virtuosity and its effects.

Further, such terms fail to capture the precise makeup of Epictetus' audience. What Arrian primarily recorded or wrote up was Epictetus' informal instruction of his students. Sometimes, the students were privy to their master's conversation with mature men passing through Nicopolis, men who were often high government officials on their way to Rome and curious to meet the renowned ex-slave turned Stoic teacher. ${ }^{14}$ But most of Arrian's material was spoken only for his and his fellow-students' ears. We can be certain that Epictetus spent a lot of his time expounding Stoic philosophy in formal classes on logic, ethics, and theology, and also on supervising senior students' instruction of beginners. ${ }^{15}$ That, however, is not what Arrian presents. On the basis of

11 See H. Schenkl, Epictefus. Dissertationes ab Arriano Digestae, ed. maior (Teubner, Leipzig, 1916, repr. Stuttgart, 1965) 1-2.

12 See Schenkl (above n. 11) xxxiii-xxxv.

13 Descriptions of the discourses as 'diatribes' persist in Dobbin's excellent book (above n.10) xxii-xxiii, and I myself followed the fashion many years ago; see A. A. Long, in T. J. Luce (above n. 10) 995-6. Its shortcomings were already pointed out by O. Halbauer, De Diatribis Epicteti (Leipzig, 1911), and the existence of the 'diatribe' as an especially Cynic/Stoic literary form has been effectively demolished by H. Jocelyn, Liverpool Classical Monthly 4.7 (1979) 145-6, and 8.6 (1983) 89-91, followed by A.E. Douglas, in J. Powell, ed., Cicero the Philosopher (Oxford, 1995) 198-9.

14 See II.4; II.14; II.24; III.4; III.7; III.9, and cf. F. Millar, 'Epictetus and the imperial court', Journal of Roman Studies 55 (1965) 141-8.

15 On Epictetus and logic, see J. Barnes, Logic and the Imperial Stoa (Leiden, 1997). I specify theology as distinct from physics for Epictetus' curriculum because he is quite reticent about the physical details of cosmology as distinct from divine providence. Why he differs in this respect from Seneca and Marcus Aurelius is much too large a question for me to explore in this paper, but 1 am sure that part of the explanation involves his very deliberate focus on Socrates as the ideal paradigm for himself and his students. See Epictetus, fr. 1, which echoes Socrates' well-known disclaimers concerning physical speculation. Barnes (25-7) offers a quite different interpretation of this text, attempting (unsuccessfully in my opinion) to find in it a proof that 'Epictetus took physics to be a necessary part of philosophical study'. Yet physics, in the sense that Barnes intends, is strikingly absent from Epictetus' triad of topics for his students to study (see III.2). 
his text, we should assume that after these classes, Epictetus elaborated on his own favourite themes, took up questions students had raised, criticised their mistakes, and dealt with numerous issues bearing on their education, daily life, future profession as philosophers, or entry into other careers. The 'discourses' are actually dialogical lessons.

They are dialogical because they regularly make use of dialogue, either explicitly or implicitly. Whether he uses the second person singular or plural, whether he is addressing an actual interlocutor or the whole class, our Epictetus regularly speaks in the way for which he praises his teacher Musonius: 'Each of us, as we sat there, thought that someone had informed on him; such was his grasp of our behaviour and his capacity to make us see our individual failings' (III.23.29). The discourses are lessons because the student audience is very young. One potential pupil is there with his father (II.14.1); another is missing his mother and his comfortable bed (III.5.12); others have problems with getting an allowance from their parents (III.17.8), or dealing with fathers who object to their studying philosophy (I.26.5-7). Difficult fathers and also brothers are frequently mentioned. ${ }^{16}$

How old was the typical student? Closer, we may surmise, to high-school leavers than to graduate students. In any case, they or at least most of them were immature (neoi), not yet launched into the world. Epictetus' persona and role are professorial in the French rather than the English sense. He sometimes calls his class 'men' (andres), but man in his usage is more normative than descriptive (see below, p. 96). The main content of Epictetus' lessons is so grown-up, demanding and tough that it comes as a shock to realise that he was largely addressing youths. Yet that, I am sure, was the case.

Now another shock. How does Epictetus characterise himself? This is a difficult question for a reason that has been virtually overlooked in the literature - his persistent use of irony and self-deprecation. To an Epicurean visitor he describes himself as a 'layman' (III.7.1). To an effeminate young man, he remarks: 'It wasn't Epictetus who said these things - how could he? - but some kindly god speaking through him' (III.1.36). He is a 'lame old man' (1.16.20) with 'no natural talent' (I.2.35), and in the eyes of a Roman philosopher, the last thing that person would want to become like (III.8.7). Whatever we make of these self-characterisations, one description he applies to himself seems straightforward enough - paideutēs, 'trainer of the young'. I quote II. 19.29-34:

So I am your trainer and you are being trained in my school. And my project is this - to make you unimpeded, unconstrained, unrestricted, free, contented, happy, looking to God in everything great and small. And you are here to learn and to practise this. Why then don't you finish the job if you have the right purpose and if $I$, besides the purpose, have the right qualifications? What is missing? ... The craftsman is here, and so too the material. What are we lacking? Is the thing

16 See e.g. III.3.9; III.10.19; III.17.8; III.21.5; III.26.8; IV.1.43; Ench. $30,43$. 
not teachable? It is ... So why don't you finish the work? Tell me the reason. For either it is due to me or to you or to the nature of the thing. The thing itself is possible and the only thing we have in our power. Therefore the failing is mine or yours or, more truly, it pertains to us both. Do you want us to begin, here and now, to execute this project? Let's say goodbye to the past. Let's simply begin, and trust me, you will see.

This passage comes at the end of the dialogical lesson which begins with Epictetus' exposition of the famous Master Argument on the truth conditions of modal propositions. After outlining the controversy, which had historically involved three mutually incompatible solutions, Epictetus imagines himself being asked which one of these he himself adopts, to which he responds: 'I don't know, but I have been given the following story ...' (II. 19. 5). Here Epictetus sets himself up as a deliberately bad model for his students, with the object of showing that if you have nothing of your own to say on a topic, it is simply vanity to give an uncritical recital of received opinions. His point is not to belittle expertise in logic, but to indicate the numerical gap he finds between those who pride themselves on clever talk or merely devote themselves to books and rote learning, and those who seriously try to form their own judgments and fashion themselves accordingly. ${ }^{17}$ Shortly before the extract I quoted, he pleads to his students:

By the gods, I would love to see a Stoic. But you can't show me one fully formed. Well, show me at least one who is being formed, one who has tended that way. Gratify me. Don't begrudge an old man the sight of what I have never seen up to now. (II.19.24)

As often, the tone of the passage is complex - genial yet plaintive, appealing yet prescriptive, half-serious and half-tongue in cheek. Epictetus plays on the famous cliché about the Phoenix-like rarity of the Stoic sage, and when we remember his youthful audience we can imagine how they must have been simultaneously amused, impressed, and challenged. Perhaps he also gives his own twist to the concept of a liberal education, interpreting this not in terms of philology, but of achieving absolute autonomy - his favourite theme. What I find most striking is Epictetus' complicity, his engagement with his students, pushing, cajoling, but in the final analysis taking joint responsibility for their success or failure.

17 See Barnes, (above n. 15), 43-55. I largely agree with his interpretation of II.19 and his recognition of Epictetus' 'heavy irony'. But I also think Epictetus is sincere when he says 'I don't know' [which option to adopt as regards the Master Argument]. His point to his students would then be: when you don't know something important, admit it, and make every effort to arrive at a critical judgment of your own. but don't trot out encyclopaedic information. For positive assessments of logic, see 1.7; I.8; 1.17; 1.27; 11.20. For criticism of mistaken priorities or mere parroting, see I.4: 1.26.9; II.9.15; II.13.26; II.16.3; II.17.34; II.21.17. 
A trainer, rather than a professorial philosopher, a teacher who, in the text just discussed, claims to have no opinion of his own on the adjudication of the Master Argument, an ethical mentor of young men, and one who elsewhere disclaims any interest in whether the world is composed of atoms or indivisibles or of fire and earth (fr. 1, see n. 15 above). Who must this remind us of? Socrates, of course, but a paternalist, rather than a paederastic Socrates, in line with Roman as distinct from Greek notions of a mentor. ${ }^{18}$

Now there is nothing surprising about a Stoic aligning himself doctrinally with Socrates. That had been the practice of the school ever since Zeno. On such fundamental issues as the unity of the virtues, the definition of the virtues as epistemic dispositions, the priority of the soul's good over everything else, and divine providence, Stoic philosophers had drawn support from Plato's and Xenophon's Socrates. ${ }^{19}$ They had also treated Socrates' life as a near paradigm of Stoic wisdom's realisation. When Epictetus repeatedly holds up Socrates' equanimity at his trial, imprisonment and death, as the benchmark of an autonomous and self-respecting person's response to a supreme test, he was following a long-standing tradition of exemplary instruction. ${ }^{20}$ It is clear from Seneca that Roman moralists had adopted Socrates as an exemplum of virtus, to be mentioned in the same breath as Cato. ${ }^{21}$ From Seneca, however, we hear nothing about Socratic dialectic; his Socrates has simply achieved sanctification. Cicero, by school allegiance an Academic not a Stoic, takes an interest in Socratic questioning and in Socrates' 'know nothing' stance, but Cicero's interest in Socrates, though often admiring, is detached as compared with what we find in Epictetus. 22

There only Zeus is named as frequently; in fact Epictetus' implicit allusions to Socrates are evident on every other page, and he frequently adverts to him explicitly in his perorations. He draws on Socrates not only as a model for public and private life and for exemplifying the practice of what he himself is trying to teach; in addition, and uniquely as far as our Stoic record goes, Epictetus uses Socrates as the model for his

18 Scholars have not missed the importance of Socrates to Epictetus, but I know of no treatment which probes it deeply, and it is barely mentioned in the classic works of A. Bonhöffer: Epictet und die Stoa (Stuttgart, 1890) and Die Ethik des Stoikers Epictet (Stuttgart, 1894). The only study that treats it with some thoroughness is K. Döring, in a chapter of his Exemplum Socratis (Wiesbaden, 1979), and his approach is more descriptive than analytical; see also A. Jagu, Epictète et Platon (Paris, 1946). Even if T. Wirth were right, in treating Arrian as the essential author of the discourses, modelling himself on Xenophon's Memorabilia (Museum Helveticum 24 (1967) 149-89, 197-216), Epictetus' Socrates echoes Plato far more than Xenophon. For criticism of Wirth, see Long (above n. 10) 989-90, and I. Hadot (above n. 10) 153-5. For an extensive selection of Epictetus' allusions to Plato's Socrates, see A. A. Long, Stoic Studies (Cambridge, 1996) 2 n. 2.

19 See A. A. Long. 'Socrates in Hellenistic Philosophy' = ch. 1 of Stoic Studies (above n. 18).

201.4 .24 ; 1.9.22-5; I.12.23; 1.29.16-19, 29, 65-6; II.2.8-9, 18; II.5.18-19; II.16.35; III.1.19-21; III.18.4; III.24.99; IV.1.123; IV.1.159-69; Ench. 46, 51, 53.

21 See Seneca, Ep. $13.14 ; 24.4 ; 64.10 ; 67.7 ; 71.16$.

22 Cicero's references to Socrates are most frequent and most engaged in the Tusculans: see I.71, 1.97-9 (the celebrated translation of Socrates' peroration from Plato's Apology), I.103, III.31, V.35-6, etc. 
own philosophy of education, and thereby too, as a model for the kind of teacher he hopes that some of his own pupils will try to emulate.

Several of Epictetus' dialogical lessons focus on the proper starting-point and methodology of philosophy. Readers of this journal will hardly need explicit signals for marking all the Socratic reminiscences and implementations, so I offer some translated excerpts with summaries in parentheses, and comment discursively on Epictetus' appropriation of Socrates. Discourse II. 11 :

The proper ... starting-point of philosophy is awareness of one's weakness and incapacity concerning essentials. [With regard to expertise in such fields as mathematics and music, we don't have illusions about knowing anything before we are taught. But we enter the world with an innate concept (emphytos ennoia) of goodness and badness and other values, and starting from these preconceptions (prolepseis), we each add on to them our own opinion, and get into disputes over applying these concepts to particular instances.] This is the starting-point of philosophy: Is everyone's opinion sound? - But how can conflicting opinions be sound? Therefore, not all opinions are sound. - Well, our opinions then. - Why ours rather than the Syrians' or the Egyptians'? Why mine rather than so and so's? - No reason. - Therefore the individual's opinion is insufficient with respect to truth.

That is why, for weights and measures, we are not content with mere appearance (emphasis), but we have discovered a certain standard (kanōn) for each. Is there here, then, no standard higher than opinion? But how is it possible that the most essential items among human beings should be indeterminable (atekmarta) and indiscoverable (aneureta). - So there is a standard. - Why, then, do we not search for it and find it, and when we have found it use it unfailingly (aparabatos) from then on, not even stretching a finger without it? ${ }^{23} \ldots$ What topic has arisen that we wish to investigate? - Pleasure. - Submit it to the standard; put it into the balance. Must goodness be the sort of thing that merits confidence and trust? - It must. - Does something insecure merit confidence? No. - Pleasure is not something secure, is it? - No. - Remove it, then, throw it out of the balance and expel it far away from the domain of goodness.

In this passage, Epictetus links Socrates' renowned prerequisite for philosophical progress - admission of ignorance - with Socrates' equally celebrated inquiry into value judgments and rational standards for establishing their truth. ${ }^{24}$ In the Euthyphro and Protagoras Plato had drawn on 'measuring' and 'weighing', to illustrate Socrates'

23 Although 'stretching a finger thus or thus' was a standard example in Stoicism of something 'absolutely indifferent in itself' ( $S V F$ 3.118), Epictetus alludes to it here to make the equally Stoic point that even this trivial action can and should be performed intelligently (phronimos;; see SVF 3.627).

24 Epictetus begins 11.17 by saying that the first task of one who does philosophy is to remove the conceit of thinking that he knows. For his concern with standards and criteria, cf. 1.11; 1.17.8; 1.28.28-30; III.3.14. 
concern with such standards. ${ }^{25}$ Epictetus invokes the balance and the carpenter's rule here (II.11.13), but by his date these examples had also become attached to the hotly debated concept of a 'criterion' of truth, defended by Stoics and rejected by sceptics. Epictetus, then, does not simply echo Socrates in our passage; he shows how his own, or Socratic 'scepticism', differs from Pyrrhonism. ${ }^{26}$ Both start from conflict of opinions and investigation of its grounds. But whereas the sceptic leaves "such utterly essential things undetermined and undiscovered' (II.11.16), Epictetus 'scepticism' is only a step on the way to a Socratic refutation of pleasure's claims to be the good. He invites an imagined interlocutor to test pleasure against two evaluative criteria: lasting stability, and production of elation. Pleasure fails the test (II.11.19-22).

It would be a mistake to interpret this as a shallow refutation of hedonism. The text does not have that as its purpose, which is rather to acknowledge the prevalence of conflicting value judgments, and to show how to submit them to tests whose authority is agreed between the parties to the dispute. Epictetus has clearly grasped the optimistic rationalism that underlies the dialectic of Plato's Socrates - I mean, the Socratic principle that intellectual and moral progress can result only from frank and sincere exchange between interlocutors. Not only does he echo Socrates directly in various of his comments on elenctic questioning, as we shall see; he also devoted an entire dialogical lesson to the issue of how to engage in philosophical discussion with ordinary people.

This text - Discourse. II. 12 - is exceptionally interesting because it purports to cast light on Epictetus' personal experience as well as his use of Socrates. As often, the text is difficult to interpret in many of its details owing to the complexity of Epictetus' style. First, a combination of summary and quotation, and readers should note that whenever I use 'we' or 'you' I am parroting Epictetus:

[Although our Stoic authorities have been quite precise in stipulating the knowledge necessary for engaging in discussion, we are quite 'untrained' (agymnastoi) in our proper application of it. None of us has the skill or the patience to complete a discussion with a lay person. Instead, we give up, and dismiss him as an idiot. In fact, if you really show him the truth, he will follow. The fault, if he doesn't, is your own incapacity.]

Socrates [Epictetus refers to Gorgias 474a] made a habit of compelling his interlocutor to be his only witness . . . because he exposed the implications of that person's concepts so clearly that whoever it was became aware of his inconsistency and gave it up. [An example of an interlocutor's inconsistent opinions

25 Euth. 7c; Prot. 356b-357a.

26 Epictetus can hardly have known the works of Sextus Empiricus, but he was clearly aware of the Pyrrhonist revival, see I.27.2, 14, where he cites Pyrrho alongside the Academic sceptics. The way he talks about conflict of opinions and the inquiry that it motivates suggests to me that he was familiar with some neo-Pyrrhonist work: cf. Sextus, $P H$ I.12 and 29. 
about phthonos follows. $]^{27}$ Socrates did not start by saying: 'Define phthonos for me', and then, when it had been defined, respond: 'A bad definition - because the definiens is not extensionally equivalent to the definiendum'. ${ }^{28}$ [Laymen have difficulty with these technicalities, but we can't give them up. Yet, we fail to move people when we do not use terms they can fit into their own conceptual scheme, and thus are able to accept or reject. The result of this dilemma is that we, or at least those of us who are cautious, recognise our inability and give up such discussion. A good many others, however, rush into it, get flustered and angry, and walk away. Socrates was not like that. He never got angry, and he put up with other people's abuse.] What then? Well, this kind of discussion isn't very safe these days, especially in Rome.

Epictetus then says that anyone practising Socratic dialectic on a lay person 'had clearly better not do it in a corner', alluding to Callicles' taunt of Socrates, but must approach some prominent figure. ${ }^{29}$ He then exemplifies such an encounter. Parodying Socrates' typical analogical reasoning from crafts, and his equally typical elevation of soul over body, Epictetus' Socratic questioner elicits from his elite respondent the answer first, that that individual regards his soul as his most valuable possession, and second that the person is not neglecting his soul. Then the questioner asks:

'Have you yourself taken care of it? Did you learn to do so from someone, or did you discover that by yourself?' So now there's the danger, first, that he'll say: 'What business is it of yours, my fine fellow; are you my master?' And next, if you persist in bothering him, he may raise his hand and slap your face. This is something I was very keen on once, before I fell into my present situation.

What are we to make of this dialogical lesson? Is it a recommendation to imitate Socrates or the reverse? Is the message a confession of Epictetus' own shortcomings as a discussant with a lay person? How are we to interpret the praise of Socrates for his effectiveness in using ordinary language, the remark that 'we' can't dispense with technical terms, and the point about 'clearly having to' engage a prominent person out in the open?

The answer to all of these questions, I believe, requires us to interpret the entire text

27 Drawing on Xenophon, Mem. III.9.8 and Plato, Philebus 48b ff. The text is too condensed to be thoroughly clear. I conjecture its sense as follows: the interlocutor starts by taking malice to be pleasure in someone else's misfortunes (cf. Plato, Phileb. 48c). Under challenge, he accepts that malice is a painful emotion, contradicting his initial claim. He then agrees that it cannot be pain aroused by others' misfortunes. So he is prompted to redefine malice as pain taken in someone else's good fortunes (cf. Cicero, Tusc. III.2I $=S V F$ 1.434), a complete reversal of his starting-point.

28 I draw on Barnes' translation, which nicely captures the pedantically logical language, Logic and the Imperial Stoa, 29.

29 See Plato, Gorgias 485d, where Callicles charges Socrates with 'twittering in a corner with three or four young men'. 
as a lesson to the students in how to apply, or rather how not to apply, the Socratic method in the everyday world of their own time.

As regards the statement, 'we' can't dispense with technical terms, Jonathan Barnes remarks: 'Epictetus is criticizing his fellow Stoics for their penchant for jargon: he is not beating his own breast; the first person plural indicates a polite complicity rather than an honest confession'. ${ }^{30} \mathrm{I}$ am sure this is right. But if Epictetus is recommending his students, unlike Stoics in general, to imitate Socrates' use of ordinary language, what does he expect them to make of his made-up Socratic conversation with the prominent Roman, the angry response it evokes, and his apparent admission of such an encounter's applicability to his youthful self at Rome?

Maybe Epictetus did have such a cautionary experience before his exile under Domitian's collective expulsion of philosophers in A.D. 92/3, but I take him in any case to be saying: Try to converse with your interlocutor on his own ground, and even in your use of Socratically leading questions, be careful not to proceed in a peremptory manner that will simply antagonise the other. The remark about having to confront a big official, in response to Callicles' taunt of Socrates, is almost certainly ironical. ${ }^{31}$ We should think of Epictetus as recommending his students to use discourse that is appropriate to their interlocutor's mind-set and social status. Readers of Plato are familiar with the way Socrates' dialectical style changes in relation to his discussants; the Gorgias, as it moves from Gorgias to Polus to Callicles is a prime example. Similarly we find Epictetus varying his dialectic in relation to the age and background of the individuals he converses with. When he meets Maximus (III.7), the Epicurean administrator, he converses with him, as one philosopher to another, and does not avoid technicalities. In contrast, when a rhetorician on his way to Rome for a lawsuit consults him about his business (III.9), he informs the man at the beginning of their conversation that the kind of advice he is qualified to offer the man cannot be provided in a brief encounter.

You will say, meeting Epictetus was like meeting a stone or a statue. Yes, you simply looked at me. Two people only meet one another when one of them understands the other's principles and exhibits his own in turn. Learn my principles, show me your own, and then say you have met me. Let us examine (elenxomen) one another. If I have a bad principle, remove it; if you have one, set it out before us. That is meeting a philosopher. (III.9.12-13)

Here we observe Epictetus drawing on the Platonic idea of dialectic as a cooperative undertaking, wherein the questioner or philosopher no less than the respondent submits

30) Barnes, Logic and the Imperial Stoa, 29.

31 That is to say, Epictetus is telling his students that they shouldn't try to outdo Socrates and shouldn't worry about Callicles' taunt. I am grateful to the journal's referee for criticising my original formulation of this point. On the other hand, I have doubts about the referee's suggestion that 'Epictetus, having tried the game [of playing Socrates on the streets of Rome] when he was younger, now thinks of himself as "Iwittering in a corner" - namely his school in Nicopolis.' For in that school he was frequently visited by prominent Romans and did not mince words in his conversations with them. 
his judgments to examination. Viewed in the light of this passage, the mock questioning of the prominent Roman (in the previous passage) was bound to fail because the conversation lacked the give and take and the mutual respect of a properly Socratic encounter.

Underlying Epictetus' conception of philosophy as having to start from one's recognition of ignorance and the insufficiency of mere opinion, are two equally Socratic notions which it is the purpose of the Socratic elenchus to expose - the involuntariness of error and the basis of error being inconsistent beliefs. In a very short but telling dialogical lesson (II.26) Epictetus states that every error involves contradiction or inconsistency $(m a c h \bar{e}) .{ }^{32} \mathrm{His}$ grounds for this claim are the Socratic principle that no one wants to err, but rather to be successful in pursuing his own good. The failure to do so involves contradiction because erring persons' assent to the truth, 'As a human being I want what is in my interests', conflicts with some other belief they have, such as 'Stealing is in my interests.' Epictetus continues:

Every rational soul is naturally averse to contradiction. But until it is conscious of being involved in a contradiction, nothing prevents it from acting contradictorily. Once it gains this awareness, it absolutely must abandon and avoid it, just as one who perceives that something is false is forcibly constrained to renounce the falsehood, though until it shows itself he assents to it as true.

Making an explicit appeal to Socrates' contentment with a single witness (a favourite passage, as we have seen), Epictetus draws the lesson for his students. The capacity to show someone that he is erring by not doing what he wants to do and by doing what he does not want to do is the mark of someone, i.e. like Socrates, who has three related qualifications - dialectical, protreptic, and elenctic expertise. He concludes:

Socrates understood the motivations of a rational soul, and the way it inclines like a scale, whether you want it to or not. Show it a contradiction, and it will desist. But if you don't show it, blame yourself rather than the person who is not persuaded.

If this recommendation sounds naively optimistic, Epictetus acknowledges its limits when he criticises sceptics in I.5. To the hard-line sceptic, who denies that he can securely distinguish between waking and dreaming, he responds: ${ }^{33}$

Am I still talking to this fellow? What kind of fire or iron can I apply to him to make him perceive that he is deadened (nenekrotai)? He does perceive it, but he

\footnotetext{
32 Texts that should be compared with II.26 include I.2.1-4, I.28.1-4, and the whole of I.1 I, which is a fullfledged 'Socratic' elenchus; there Epictetus exposes the contradictoriness of a man who believed he was motivated by love in absenting himself from his daughter's sick-bed.

33 For this sceptical strategy and Stoic responses to it, see Cicero, Acad. II.51, 88.
} 
pretends not to. He is still worse than a corpse. One person is unaware of the contradiction; he is in a bad way. Another is aware of it but makes no move or progress; he is in a still more miserable state.

The sceptic is a living contradiction, a sentient corpse as it were, because he wilfully refuses to acknowledge the incompatibility between scepticism (death) and life. Epictetus concludes with an image designed to appeal to his audience of male youths: the sceptic has lost his 'moral balls': his integrity (aidèmon), punning on aidoia (meaning genitals), has been lopped off (ektetmettai). ${ }^{34}$ As if this were not strong enough, Epictetus likens the sceptic to the utterly uninhibited pathic (kinaidos). Yet, there is hope even for the sceptic because his 'rationality' (logikon), though it has been 'bestialized' (apotethēriōtai), is still intact (ouk apotetmètai).

\section{IV}

We have already encountered Epictetus' claim (II.11) that all human beings have innate concepts (emphytoi ennoiai) of value. ${ }^{35}$ 'These 'preconceptions' (prolèpseis), as he often calls them, involve such content as 'the profitability of goodness' and the 'unequivocal desirability of happiness'; and they cannot, he says, conflict with one another. Conflict arises when we misapply them to particular circumstances, or when we develop patterns of thought and belief that misidentify some particular thing as good or as productive of the happiness we all naturally want. ${ }^{36}$ Hence the need, as he never tires of saying, for us to make 'correct use' of our moment-by-moment thoughts (phantasiai), to check them against our preconceptions and the fundamental doctrines of Stoic philosophy.

Rather than elaborating this familiar theme, ${ }^{37}$ I want to show how precisely it relates to Epictetus' alignment of his methodology with Socrates. The constant injunction to make correct use of impressions is Epictetus' explicit interpretation of the Socratic claim that an unexamined life is not worth living. ${ }^{38}$ And for Epictetus, as for Socrates, the requisite examination is elenctic testing of beliefs for consistency or lack of consistency.

In Epictetus' account of involuntary error, we have noticed his extraordinarily optimistic rationalism: clearly show someone that his or her present behaviour or set of values is inconsistent with what they really want for themselves - i.e. long-term

34 I owe this point to James Ker.

35 In making this claim, Epictetus differs from his early Stoic authorities for whom the mind is a tabula rasa at birth. They accepted that concepts of value arise 'naturally', as rationality develops, but Epictetus, as a later Stoic influenced by Platonism, adopted the stronger notion of inborn preconceptions: see F. $\mathbf{H}$. Sandbach. 'Ennoia and Prolepsis', in A. A. Long, ed., Problems in Stoicism (London, 1971, repr. 1996) $29-30$.

36 See $1.22 ; 1.28 ;$ II. $17 ;$ II. $18 ; 111.3$.

37 I have discussed it in detail in Stoic Studies (above n. 18) 275-85.

38 Plato, Ap. 38a: see Epictetus III.12.15. 
happiness - and they will recognise their mistake. The cogency of this recommendation rests on the assumption (1) that human beings are natural truth- and consistency-lovers, and (2) that they possess true beliefs or preconceptions concerning their own good which, when brought to light and properly articulated, will cause them to abandon their false and inconsistent beliefs. Thus, Medea, one of Epictetus' favourite examples, went astray because she failed to recognise that killing her children, to spite Jason, was inconsistent with her long-term good:

Show her clearly that she is deceived, and she will not do it; but so long as you do not show her, what else has she to follow but what appears to her to be true? (I.28.8)

Epictetus has anticipated Gregory Vlastos' interpretation of the Socratic elenchus. ${ }^{39}$ Vlastos wanted to understand how Plato's Socrates, in exposing the inconsistency of an interlocutor's beliefs, could reasonably claim that the outcome of the argument was both a refutation of the interlocutor's initial thesis and an endorsement of Socrates' counter-proposal. Why would the outcome not simply be an awareness of inconsistency? The answer, Vlastos proposed, requires a twofold assumption: first, that any set of entirely consistent beliefs, beliefs that have withstood constant testing, must be true; and second, that whoever has a false moral belief will always have at the same time true beliefs entailing the negation of that false belief. Socrates finds that his own beliefs, because their consistency has been thoroughly tested, satisfy the first assumption, and in the elenchus he elicits from his interlocutor latent but true beliefs, which are found to cohere with Socrates' own.

Epictetus' rationale for his use of the elenchus is exactly parallel. He assumes that its qualified practitioner has the beliefs that can correct erring persons; and he also assumes that erring persons have the true preconceptions which, when brought to light, will enable them to correct their false beliefs.

I have emphasised Epictetus' appropriation of the Socratic elenchus because of the light it casts both on his philosophy of education and also on his constant insistence that errors of judgement are at the root of people's failure to live free from frustration and emotional disturbance. However, elenctic confutation is no more than the first step in his training regimen, and his recourse to Socrates cuts much deeper. Epictetus is always telling his students that mastering theory is relatively easy; the hard thing is the digestion of theory, keeping it down, developing ethical muscles from Stoic nutriment (111.21.1-3). Socrates, he says, focused on his self-improvement every day (111.5.14). Hence he was able to write paeans in prison (II.6.26). We can be virtually certain that Epictetus got his students to read such Socratic dialogues as the Crito and the Gorgias, but he warns them at their stage of education against trying their own hand at such compositions (II.1.31-3). When they write, they should do so, as Socrates himself did,

39 See G. Vlastos, Socratic Studies, ed. M. F. Burnyeat (Cambridge, 1994) 1-29, esp. 22-9. 
in the absence of an interlocutor, 'subjecting himself to an elenctic examination, constantly putting one of his preconceptions into training for practical use'.

Here again, Epictetus updates Socrates, modelling his paradigm on the contemporary practice of self-monitoring by means of the kind of written notes Marcus Aurelius addressed to himself. And here too the updating is justified by an authentic reminiscence of the Platonic Socrates - in this case, his insistence on the need to live an 'examined life'. We have seen how Epictetus' reliance on people's stock of valid preconceptions about their own good ties in with his interpretation of the Socratic elenchus. Now, in his fiction about Socrates' daily writing, he connects his own constant admonition to monitor one's thoughts and sense impressions with Socrates' famous injunction concerning the testing of one's life. ${ }^{40}$

Some of Epictetus' pupils had ambitions to become philosophers; others were destined for military or civil careers. Could the historical details of Socrates' life be applicable to so diverse a group? Seneca, as I have mentioned, places Socrates in the band of the highest Roman saints, but Epictetus is far more subtle. In many contexts he presents Socrates as an example of the preeminent figure whom very few, including himself, have the natures to equal (1.2.33) - a man who, notwithstanding his family and other circumstances, discounted everything except what he thought was right (IV.1.159). Yet Socrates also serves Epictetus as the model of someone who lived an ordinary life with a wife and with children that he loved (III.26.23; III.24.60), served well as a citizen and soldier, and in spite of Aristophanes' calumny and maybe infrequent bathing too, was agreeable in appearance (IV.11.20). The point, of course, is that Epictetus' brand of Stoic training is intended not just for heroes but for all kinds of young men; while it is intended, at the limit, to fortify them in face of the severest challenges, it is no less focused on cultivating a disposition to eat, and bathe, and dress, and interact in daily life as a free, self-respecting, and decent civilian.

If these last observations sound bland or at least unexciting, we need only sample a page or two, in order to appreciate that, in Epictetus' style of dialogical teaching, living well in everyday life is a project he cajoles his students into treating like training for the Olympics or for a military campaign. ${ }^{41}$ Yet, they are not to call themselves 'philosophers' (Ench. 46), but let their philosophy be observed through their actions. We have already remarked Epictetus' reluctance to call himself a philosopher, and in advising his students similarly he invokes Socrates, noting that 'people failed to recognise him, and asked him to introduce them to philosophers' (IV.8.22). ${ }^{42}$

4) There is much more to be said about Epictetus' elenctic procedure than I have room to explore in this paper. I devote a chapter to it in the book on Epictetus that I am writing (above n. 1).

41 See I.24.1-2; III.24.31.

42 This is probably an adaptation of Plato, Tht. $15 \mathrm{lb}$, where Socrates says he has consigned numerous young men who have not "conceived' to Prodicus and other sophists. 
Why this reticence about the term and why call on Socrates for that? Epictetus' dialogical lessons are packed with warnings against parading oneself as a philosopher, showing off one's logical skills, putting on finery to lecture, and so forth. He praises Euphrates, his older contemporary, for disguising his philosophical identity, saying: 'What harm was there in having the philosopher that I was, recognised by what I did, rather than by the outward signs?' (IV.8.20). Clearly, it befits a Stoic to disparage the value of mere appearance (something morally 'indifferent') in order to emphasise what really matters - one's internal disposition and purpose. It's equally clear from stock jokes about weird Cynics and philosophical hypocrites that any teacher as serious as Epictetus would want to remove himself and his pupils from any suspicion of falling into such categories. In addition, Epictetus knew what it was to be banished from Rome. Was caution a factor in his reticence about the label 'philosopher'?

We can firmly dispel this suggestion. Epictetus gives no scope to caution when it is a question of one's material safety (II.1), and in illustrating strength of character he even says that to the command 'Shave off your beard, Epictetus', he would retort, 'If I am a philosopher, I will not do so' (I.2.29). Nor is the point about Stoic indifference to externals a sufficient explanation. Zeno and the other early Stoics strongly professed that doctrine, yet they are not known to have shown reluctance to accept the title of philosopher. It's clear too that, notwithstanding his 'layman' and 'trainer' postures, Epictetus knows he is a philosopher, and that he is so regarded. When he tells his students that they should regard the philosopher's school as a clinic (III.23.30) and that genuine philosophers, unlike contemporary doctors at Rome, don't advertise for patients (III.23.27), he is referring to himself.

To resolve this puzzle and to account for Epictetus' irony, we should distinguish, as the Greek does not, between philosopher with a capital letter and philosopher uncapitalised. Epictetus disclaims being a capitalised philosopher. He does not want to be taken for a popular lecturer or sophist, for a Favorinus or a Dio, someone who puts on epideictic displays of erudition..$^{43}$ Modern writers on the Second Sophistic remark that at this date the categories of rhetorician and philosopher have merged into the composite label 'sophist'. ${ }^{44}$ That is true for a good many texts, but it strictly applies only to capitalised, self-styled, philosophers, and not to the likes of Euphrates and Epictetus.

Epictetus makes it crystal clear that he has no time for the 'display' genre of discourse. He engages an actual or imaginary student in the following dialogue:

When you are gasping for applause and counting your audience, are you wanting to be of benefit to others? - Today I had a much larger audience. - Yes, it was big. - Five hundred, I think. - Nonsense, make it a thousand. - Dio never had

43 At III.21.19 and III.23.33 Epictetus endorses three styles of discourse - protreptic, elenctic, and instructional (didascalic), assigning them to Diogenes, Socrates, and Zeno respectively. In the second passage he discredits there being a fourth, epideictic style.

44 Cf. C. P. Jones, The Roman World of Dio Chrysostom (Cambridge, Mass., 1978) 9-13. 
such a large audience. - No, how could he? - And they were really nifty at getting my points. - Beauty, sir, can move even a stone. [And now, with heavy irony to the rest of the class.] Wow, listen to the words of a philosopher, the character of humanity's benefactor! Here's a person who has listened to reason, who has read [aloud] the Socratic literature in the genuinely Socratic way and not as something by Lysias and Isocrates . . . You have been reading it as if it were an operatic libretto. (III.23.19-21)

The Dio referred to is almost certainly Dio of Prusa. Epictetus and he may have known one another because Dio was also, in all likelihood, a student of Musonius Rufus, but their lives and styles went in very different directions: ${ }^{45}$ Dio the courtier and the modern equivalent of a television chat-show personality; Epictetus, shunning fame and teaching his young students in provincial Nicopolis. Dio is pertinent to my theme not only because of being a capitalised philosopher, but also by way of contrast to Epictetus in his frequent mentions of Socrates.

Unlike Epictetus, Dio is always talking about himself. Speaking at Athens on his return from exile, he presents himself as a second Socrates (13.9-15). An oracular response has guided his life. In his wanderings, though he has declined to be called a philosopher, people have consulted him about goodness and badness, and he addressed them with 'the trite old words' of a certain Socrates, preaching that Socratic education is indispensable for personal and civic well-being. Elsewhere he likens his own ignorance to that of Socrates, in contrast with the fifth-century sophists, draws attention to his unkempt appearance, insists that he is no flatterer (33.14; cf. Oration 54). In a lecture to the citizens of Prusa, he refers to charges against himself, by some blackmailer (43.9-12): 'I am not surprised at my present troubles; since even the famous Socrates, whom I have often mentioned, did everything for the people during the tyranny of the Thirty', but was slandered and put to death under the restored democracy. Dio goes so far as to describe the indictment against himself as 'larger and almost nobler', starting with his failure 'to honour the gods with sacrifices and hymns and annulling the ancestral festivals' (43.11).

I prefer not to quote more. Unlike Epictetus, Dio's recourse to Socrates is as trite and self-serving as he disingenuously says. The more he professes his own Socratic ignorance (e.g. 12.5 and 12.13-14), the less his words bear credence, coupled as they are with his tasteless identification with Socrates. Dio's fraudulent allusions to Socrates give us the measure both for assessing Epictetus' quite different uses of the Socratic paradigm, and also for his refusal to be a capitalised philosopher.

Checking the index of Epictetus' vocabulary, I was struck by two facts: first, his only attested use of ho sophos to refer to the ideal Stoic sage occurs in a Latin text (fr. 9), translated by Gellius from a lost book, where Epictetus is expounding old Stoic doctrine; otherwise his usage of sophos is generally ironical, and applied to Epicureans

45 On Dio's study with Musonius, see Jones (above n. 44) 12-14. 
or other would-be philosophers. ${ }^{46}$ Secondly, his preferred terms for male excellence are kalos kagathos or agathos anēr, or simply anēr or anthropos with the connotation 'manly' or 'properly human' respectively. The last two usages are very much his own; the first two, I need hardly say, hark back to the earliest Socratic literature as does Epictetus' liking for 'slave' to refer to persons who fall short of true manliness or male excellence. ${ }^{47}$ These linguistic points are central, I think, to Epictetus' conception of his educational mission, his placing of himself within Graeco-Roman culture, his Socratic interpretation of his Stoic lineage, and his concern to distance himself from capitalised philosophy.

We should take Epictetus to be taking a stand on male gender roles. For the Roman elite of his time, what constitutes a man was probably more open to debate than it had ever been before. Crazy emperors, affluence and education had muddied a question that was hardly to be settled by brusque appeals to physiology. In her fine book, Making Men, Maude Gleason discusses the careers of the rhetoricians Favorinus and Polemo. ${ }^{48}$ As rhetoricians, they offered themselves as models of elite male deportment, but Favorinus was actually a biological eunuch. Gleason shows how Polemo, in his conventionalist Physiognomy, ridicules Favorinus for his ambiguous gender and attributes sexual perversity to him. Favorinus, on the other hand, notwithstanding his physical peculiarity, 'reveals by exaggeration some of the basic dynamics of self-presentation for aristocratic males in his culture' (p. 20).

Gleason makes only passing mention of Epictetus, but her focus on education in normative male roles is even more applicable to him than to the rhetoricians whom he deplored. Epictetus takes the biological differences between the sexes to be "natural signs' that it is wrong to conceal (I.16.9-14); he has no sympathy for males who make a fetish of shaving themselves all over (III.1.31). His general principles, of course, are as applicable to women as to men (cf. II.7.8), and in enunciating his principles he prefers the unmarked term anthrōpos to anēr. ${ }^{49}$ But Epictetus' actual students appear to have been exclusively male, like those of Socrates, and it is primarily as young males that he addresses them. As two striking instances, note the following: 'Epicurus castrated (apekopsato) everything that belongs to a man (anēr) and the head of a household' (II.20.20); and 1.2.26: an athlete, who chose death in preference to castrated survival, 'died not as an athlete or philosopher, but as a man (anēr)'.

Here we glimpse again the rationale of Epictetus' reticence about capitalised philosophy and wisdom. His language of learning to be and to act like a real man is

46 See I.23.3; II.12.22; II.21.11; III.13.22; IV.11.24. He occasionally uses spoudaios and phronimos; cf. I.7.3, 25, 29; 2.22.3; III.6.5, but note his irony at I.19.17-23, II.21.9, and III.22.37.

47 See Plato, Tht $.172 \mathrm{c}$ ff. where the servitude of the time-serving politican is contrasted with the freedom of the philosopher; Xenophon, Mem. I.1.16 on Socrates' distinction between those with moral knowledge, who are kaloikagathoi and the 'slavishness' of the morally ignorant.

48 Its further title is Sophists and Self-presentation in Ancient Rome (Princeton, 1995).

49 Nothing that Epictetus says is inconsistent with Musonius' striking defence of women's natural suitability for philosophy and for being educated similarly to males (Discourses III and IV, ed. Hense), but his reticence on the subject fits his general focus on the training of young men. 
both conservative and contemporary. It resonates back to Socrates, it conforms to traditional Roman preoccupation with vir/virtus, and it sets his own distinct mark on the educational possibilities and controversies of his own time. The parents who sent their sons to Nicopolis to study under Epictetus may have had a smattering of Stoic philosophy (who knows?), but what they were primarily looking for, I guess, and what they knew in advance to expect was that he would help to turn their boys into men.

They probably did not know that Epictetus would seek to satisfy their aspirations with the Socratic rigour that I have been discussing - that he would urge their sons to think of themselves as carrying God around inside them, recalling Socrates' special daimonion perhaps. ${ }^{50}$ Nor are they likely to have had any inkling of Epictetus' persistent wit and irony. That is too large a topic to deal with adequately here, but I will mention one instance before concluding.

After contrasting Socrates' submission to condemnation with the behaviour of tragic protagonists, Epictetus says (I.4.26):

What are tragedies but the poetic exhibition of the sufferings of human beings who have been bedazzled by external things? For if one had to be deceived into learning that none of things external and outside the will (aproairetonn) concerns us, ${ }^{51} \mathbf{I}$ at least would prefer this deception as the basis for a serene and untroubled future.

Gisela Striker is puzzled by this passage because, taken at face value, it seems to negate a Stoic's commitment to holding only true and consistent beliefs. She suggests that what Epictetus may have meant is not 'deceived into believing something false', but gaining a true belief by something like clever indoctrination or hypnosis. ${ }^{52}$ Initial puzzlement is in order, but I favour a different solution. Immediately following his remark about the deception he would prefer, Epictetus imagines Chrysippus saying:

That you may know that those things are not false on which serenity depends, take my books, and you will know that what makes me tranquil is consistent and harmonious with nature. (I.4.28)

We should regard the earlier remark about 'preferring deception' as a counterfactual hypothesis, rhetorically motivated by the real deception afflicting the likes of Priam and Oedipus. Epictetus is saying: If one had to be deceived one way or the other, I would prefer a deception that gave me tranquillity! But thanks to Chrysippus, we actually know that Priam and company had a completely erroneous grasp of things. The remark about deception is a tease, a mere foil, to set up the laudation of Chrysippus as discoverer of truth.

50 See II.8.12-13; and cf. I.14.11-14, and for Socrates' daimonion, III.1.19.

51 Epictetus alludes to his most strongly emphasised doctrine; hence Arrian places it first in his edition of the Discourses and in the Mamual.

52 Essays on Hellenistic Epistemology and Ethics (Cambridge, 1996) 194. 
To conclude. Epictetus was a Stoic, but the voice he utters is consistently Socratic, not only in much doctrine and methodology but also in allusion, style, irony and deliberate abnegation of superior expertise. Often, to be sure, his manner is hectoring and hyperbolical, but so too is Socrates in numerous passages of Xenophon and Plato. Moderns, in quest of the historical Socrates, like to confine Socrates' identity to the wholly questioning and 'know nothing' figure of a few Platonic dialogues, but Epictetus saw no reason to exclude the homiletic and protreptic persona of Socrates, evident from Plato's larger canvas and from Xenophon.

I have said more by way of illustrating Epictetus' Socratic mentorship than about why he adopted this stance. That question is too large for proper study in a single paper, but I have glanced at the capitalised philosophers and rhetoricians, so different from Epictetus, the lower-case prototypes of Musonius and Euphrates, and the conception of philosophy as training boys to become men. For Epictetus philosophy is living every moment with self-conscious care and reflexive understanding as distinct from researching theories or publicly declaiming expertise. So too with Musonius and Euphrates. The best model for these totally committed Stoics had to be Socrates - a Socrates, moreover, who would have no more in common with the big names of the Second Sophistic than Plato's Socrates had had with Gorgias and Protagoras.

Tom Wolfe's novel is naturally unconcerned with this. Still, whether designedly or not, it captures two of my main points. First, Conrad, the character who discovers Epictetus, is a very young man - a person open enough to respond to the challenging words that he reads. Second, as the book's title, A Man in Full, conveys, Stoicism figures not as esoteric training of the intellect but as catalyst for changing the main character from something ordinary into what Epictetus called becoming 'the purple stripe in the toga', stealing a marker from political language to boost the philosopher's status (I.2.18). That is not our modern conception of philosophy, but we had better not ignore it if we want to understand Epictetus, Epictetus' Socrates, Epictetus' culture, and perhaps the modern appeal of Wolfe's book. ${ }^{53}$

\section{UNIVERSITY OF CALIFORNIA, BERKELEY}

A.A.LONG

53 Modern assessments of Epictetus are bound to differ greatly, as with anyone who takes so strong a line. Against Wolfe's novel, set the following comment by Barnes (above n. 15) 25: "If there is something obscurely admirable about his dogged idealism, it is difficult to avoid the thought that the attitudes which he recommended are both humanly impossible and morally disgusting.' Barnes, I surmise, is troubled about Epictetus' insistence that nothing outside one's own mind-set and purpose, including one's closest family, should ever be of ultimate concern or treated as part of oneself. 